\title{
Did COVID-19 Lockdown Restrictions have an Impact on Biomass Burning Emissions in Sub-Saharan Africa?
}

Special Issue:

Special Issue on COVID-19 Aerosol Drivers, Impacts and Mitigation (XII)

\section{OPEN ACCESS}

Received: July 30, 2020

Revised: November 13, 2020

Accepted: November 17, 2020

\section{${ }^{*}$ Corresponding Author:}

mkganyago@sansa.org.za

\section{Publisher:}

Taiwan Association for Aerosol Research

ISSN: $1680-8584$ print

ISSN: 2071-1409 online

(c) Copyright: The Author(s). This is an open access article distributed under the terms of the Creative Commons Attribution License (CC BY 4.0), which permits unrestricted use, distribution, and reproduction in any medium, provided the original author and source are cited.

\author{
Mahlatse Kganyago ${ }^{1,2^{*}}$, Lerato Shikwambana ${ }^{1,2}$ \\ ${ }^{1}$ Earth Observation Directorate, South African National Space Agency, Pretoria 0001, South Africa \\ ${ }^{2}$ School of Geography, Archaeology and Environmental Studies, University of the \\ Witwatersrand, Johannesburg 2050, South Africa
}

\section{ABSTRACT}

Across Sub-Saharan Africa (SSA), biomass burning for land clearance, grazing management, and eradication of invasive plant species emit various pollutants into the atmosphere and thus affect air quality, human health, and microclimates. The seasonality of fire events generally follows that of rainfall. Since the outbreak of COVID-19 in Africa in February 2020, several countries have implemented lockdown regulations that restrict mobility, trade, and other socio-economic activities. It is not clear how the lockdown restrictions would affect wildfire spread, density, and emissions. This study sought to address this gap by analysing changes in Black Carbon (BC), smoke+polluted dust AOD, and Carbon monoxide (CO), as well as the burned area (BA) and fire density using multi-source data at periods consistent with lockdown restrictions. Generally, the results indicated an increase in emissions (CO, BC, smoke+polluted dust AOD) due to COVID-19 lockdown. Specifically, increases of $0.008 \mathrm{~mol} \mathrm{~m}^{-2}$ in $\mathrm{CO}$ and $20 \%$ in smoke+polluted dust AOD were observed in the SSA region during COVID-19 lockdown. The majority of emissions resulted from the burning of forest cover (FC), cultivated lands (CL), and shrublands (SL) due to escaped fires from agricultural activities. The BA and fire density were also higher in the COVID-19 year (2020) than the previous year (2019), which was suspected to be caused by the closure of or not fully operated fire authorities due to the COVID-19 lockdown. The increasing biomass burning emissions, as shown here, have important implications for air quality and public health.

Keywords: COVID-19, Wildfires, Atmospheric emissions, Sentinel-5P, MODIS

\section{INTRODUCTION}

Globally, the outbreak of the novel coronavirus infectious disease 2019 (COVID-19), caused by severe acute respiratory syndrome coronavirus 2 (SARS-CoV-2), has had devastating socioeconomic impacts, thus threatening the health, lives, and livelihood of billions of the world's populations (Guo et al., 2020; Mackenzie and Smith, 2020). To mitigate the risk of infection for the general population, countries across the globe have introduced various pragmatic strategies, which included social distancing, intensive testing, face masks, isolation or home quarantine, personal hygiene, education, and lockdown (Cheng et al., 2020; Jacob et al., 2020; Kim, 2020; Lotfi et al., 2020). Among these strategies, the strict lockdown measures have been the most devastating to most economies and social-economic imperatives.

In contrast, several studies (Baldasano, 2020; Kumar, 2020; Menut et al., 2020; Otmani et al., 2020) report the positive effects of lockdown imposed by the government on air quality due to restricted anthropogenic and industrial activities. For example, Kumar (2020) reports a drastic reduction in aerosols (AOD) and nitrogen dioxide $\left(\mathrm{NO}_{2}\right)$ of approximately $60 \%$ and $45 \%$, respectively, in India between 2015 and 2020. Moreover, the study found reductions in surface $\mathrm{PM}_{2.5}, \mathrm{PM}_{10}$, and $\mathrm{NO}_{2}$ in six Indian mega cities. In Spain's two largest cities, i.e., Madrid and Bacerlona, Baldasano (2020) reports the reductions in $\mathrm{NO}_{2}$ concentrations of $62 \%$ and $50 \%$, 
respectively, during March 2018, 2019, and 2020, attributed to low traffic during the lockdown. These findings are critical for reducing respiratory diseases and deaths linked to pollutants, thus eliminating the potential worsening of the condition of COVID-19 patients and burdening hospitals. However, the effect of lockdown on wildfires emissions has been limitedly studied, especially in Africa, where the majority, i.e., 90\%, of wildfires are caused by anthropogenic activities (Andela and Van Der Werf, 2014; Archibald, 2016; Zubkova et al., 2019).

Across Sub-Saharan Africa (SSA, $25^{\circ} \mathrm{N}$ and $35^{\circ} \mathrm{S}$ ) region, fire is used as an agricultural and land management tool for crop expansion, grazing management, removal of invasive species, and hunting (Le Page et al., 2010). Thus, apart from lightning strikes, human activities constitute the primary fire ignition sources (Archibald, 2016). Moreover, other anthropogenic fire alterations include fire suppression, fuel amount and connectivity changes, and changes in the seasonality of the fires. Despite their role in promoting species diversity and vegetation regeneration in some terrestrial ecosystems, fires have been linked to accelerated land degradation, deforestation, and the proliferation of alien invasive plants (Davies et al., 2010; Allen et al., 2011; Esteves et al. 2012). Furthermore, the adverse effects on Earth's radiation balance, precipitation, air quality, and visibility, and increase in greenhouse gas (GHG) emissions have been reported (Randerson et al., 2012; Giglio et al., 2013; De Sales et al., 2016; Zielinski et al., 2016). Specifically, Shikwambana (2019) observed the highest black carbon (BC), organic carbon (OC), and smoke AOD in the southern hemisphere $\left(3^{\circ}-22^{\circ} \mathrm{S}\right)$ during June-July-August (JJA) period and lowest emissions during March-April-May (MAM) period using data from the Modern-Era Retrospective analysis for Research and Applications-Version 2 (MERRA-2) and Cloud-Aerosol Lidar and Infrared Pathfinder Satellite Observation (CALIPSO) over 11 years. In another study, Kganyago and Shikwambana (2019) characterised surface-atmospheric effects of SSA fires over nine years using multi-source data. Their results show considerable emissions and distributions of $\mathrm{BC}$, smoke, $\mathrm{CO}$, and burned area $(B A)$ in the northern hemisphere $\left(8^{\circ}-12^{\circ} \mathrm{N}\right)$ during December-January-February (DJF) period. Critically, the periods in which these emissions were prevalent, i.e., DJF, is consistent with the first cases of COVID-19 in the SSA region (i.e., February 2020), while the low emission period, i.e., MAM, corresponds to the start of lockdown restrictions (i.e., March) in the region. Therefore, these periods provide an experimental design for studying the effect of lockdown restriction on wildfire emissions.

This study sought to assess the effect of lockdown restrictions on wildfire emissions in SSA using multi-source data. Specifically, data from MERRA-2, Sentinel-5P, and CALIPSO were used to characterise the differences in spatial distribution and concentration of black carbon (BC), Carbon monoxide ( $\mathrm{CO}$ ) and smoke+polluted dust, respectively, at periods consistent with lockdown restrictions in the reference year (i.e., 2019) and COVID-19 year (i.e., 2020). Further, Moderate Resolution Imaging Spectroradiometer (MODIS) Burned Area (MCD64A1) and Fire Location (MCD14ML) products were used to characterise the burned area (BA) and fire density at the same periods. We hypothesise that the wildfire emissions will be reduced, and fire patterns altered due to limited human activities and low prospects for agricultural expansion due to unprecedented trade and export restrictions. Moreover, accidental fires and wildfire outbreaks from gas flaring and venting associated with petroleum exploration (Ite and Ibok, 2013), are expected to be reduced as a result of the shutdown of most economic activities by governments.

For simplicity, lockdown regulations by the South African government are used, i.e., before lockdown: 01 February-26 March, Level-5 lockdown: 27 March-30 April, and Level-4 lockdown: 01 May-31 May. An initial lockdown lasted for 35 days, while later, five lockdown levels (i.e., Level 1-5) were also proclaimed (see https://sacoronavirus.co.za/). These levels, termed COVID19 Risk-Adjusted Strategy, were designed to ease lockdown restrictions gradually to reduce the social and economic costs (WHO, 2020). By April and May 2020, most SSA countries had started to ease lockdown restrictions to allow some sectors of the economy to operate (Giles and Mwai, 2020; Kuwonu, 2020).

\section{METHODS}

\subsection{Study Area}

Sub-Saharan Africa (SSA) is located at latitudes: $25^{\circ} \mathrm{N}$ and $35^{\circ} \mathrm{S}$ (Fig. 1). The SSA is home to 


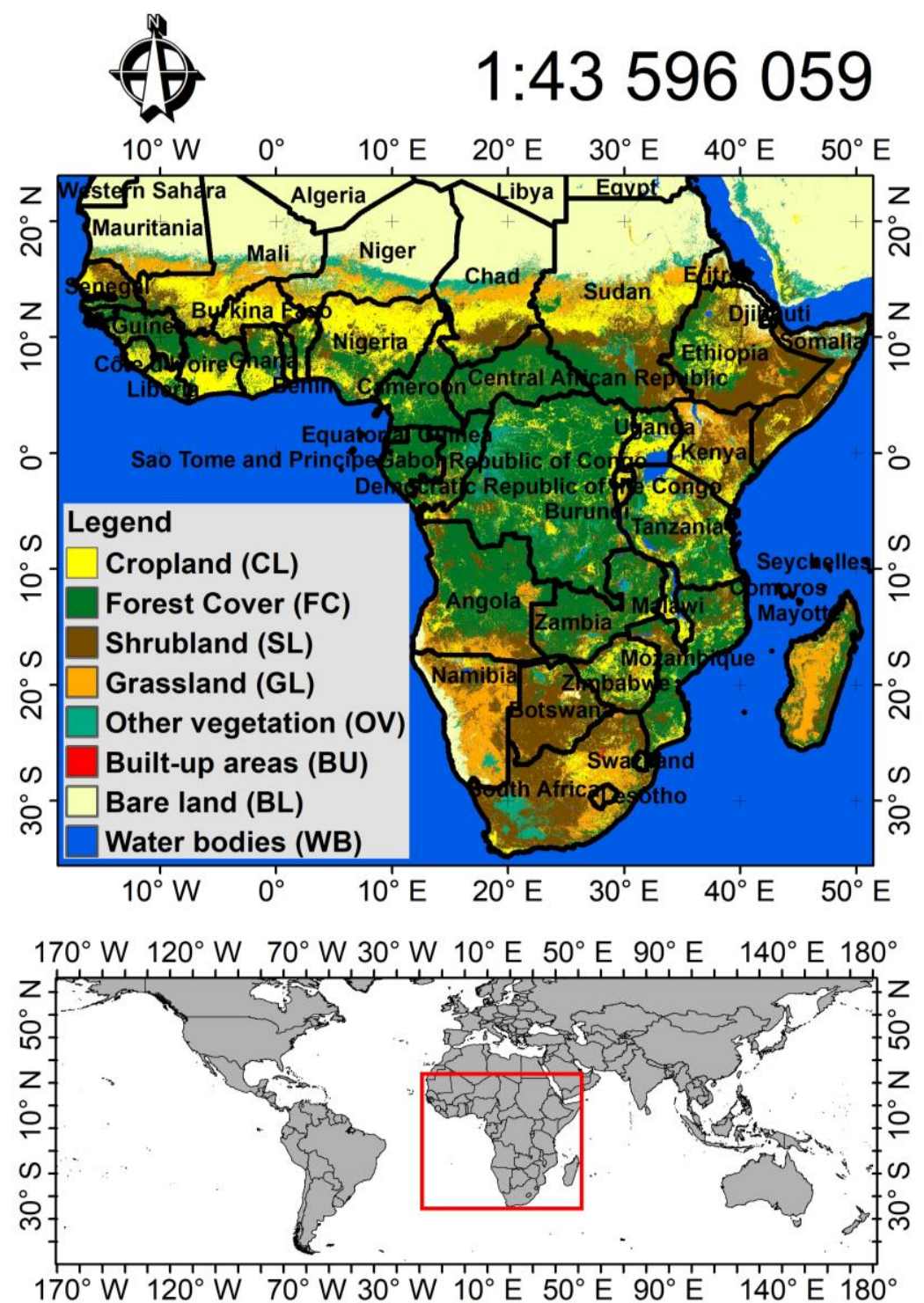

Fig. 1. Land cover and locality of Sub-Saharan Africa in the context of the world.

1.107 billion people (https://data.worldbank.org/country/ZG), contributing most to Africa's population position, i.e., second, in the world. This area is characterised by Afrotropical ecoregion that consists of eight terrestrial biomes that are habitats to thousands of terrestrial mammals, vascular plants, herpetofauna, and birds (Olson et al., 2001; Burgess et al., 2004; Wilson and Primack, 2019). Generally, fire occurrence is mostly due to anthropogenic activities, i.e., $90 \%$, which contribute approximately $70 \%$ and $50 \%$ to the total burned area and fire-related carbon emissions worldwide, respectively (Van der Werf et al., 2010; Giglio et al., 2013). The periods October-March and April-October constitute the dry seasons in the northern hemisphere (NH) and southern hemisphere $(\mathrm{SH})$, respectively. Thus, fire seasonality is consistent with these seasons, peaking in December-January in the NH and August in the SH (Boschetti and Roy, 2008; Zubkova et al., 2019).

\subsection{Fire Emissions and Characteristics}

Black Carbon: Black carbon concentration products, from 01 February to 31 May 2020, were obtained from the MERRA-2 (Rienecker et al., 2011). MERRA-2 is created with version 5.2.0 of the Goddard Earth Observing System Model, Version 5 (GEOS-5) ADAS with a $0.5^{\circ}$ latitude $\times$ $0.625^{\circ}$ longitude $\times 72$ layers model configuration (Gelaro et al., 2017). MERRA uses threedimensional variational data assimilation (3DVAR) analysis algorithm based on the Grid-Point 
Statistical Interpolation (GPS) scheme with a 6-h update cycle. MERRA uses extensive satellite data (including hyperspectral data) from both operational and research instruments. Aerosol and meteorological observations in MERRA-2 are jointly assimilated within the Goddard Earth Observing System Model, Version 5 (GEOS-5) (Buchard et al., 2015, 2016). GEOS-5 assimilates MODIS, Advanced very high-resolution radiometer (AVHRR), Multi-angle Imaging SpectroRadiometer (MISR), and AErosol RObotic NETwork (AERONET) data. A detailed description of MERRA can be found in Rienecker et al. (2008, 2011).

Carbon Monoxide: Carbon monoxide (CO) trace gas data, from 01 February to 31 May 2020, was obtained from the TROPOspheric Monitoring Instrument (TROPOMI) onboard Sentinel-5P (Precursor). TROPOMI monitors the density of a wide range of aerosols, cloud distributions, and atmospheric trace gases such as ozone $\left(\mathrm{O}_{3}\right), \mathrm{NO}_{2}$, methane $\left(\mathrm{CH}_{4}\right)$, sulfur dioxide $\left(\mathrm{SO}_{2}\right)$, and $\mathrm{CO}$ at a high temporal, i.e., 1-day, and spatial resolutions, i.e., $3.5 \times 7 \mathrm{~km}^{2}(0.01 \times 0.01$ arc degrees) (Theys et al., 2019; Omrani et al., 2020a). This capability is enabled by its broad spectral coverage in ultraviolet and visible regions (270-500 nm), near-infrared region (675-77 nm), and shortwave infrared region (2305-2385 nm) (lalongo et al., 2020; Omrani et al., 2020b).

Smoke and Polluted Dust AOD: Smoke and polluted dust AOD data, from February to April 2020, were retrieved from the Polarisation (CALIOP) lidar onboard the Cloud-Aerosol Lidar and Infrared Pathfinder Satellite Observation (CALIPSO) satellite. The CALIOP instrument is a twowavelength (1064 $\mathrm{nm}$ and $532 \mathrm{~nm}$ ), polarisation-sensitive elastic backscatter lidar that has provided global aerosol and cloud profile measurements since 2006. A detailed description of CALIOP and a discussion on the algorithms that were developed to identify aerosol and cloud layers to retrieve a variety of optical and microphysical properties is given by Winker et al. (2009). Details of CALIPSO can be found in Winker et al. (2003) and Winker et al. (2010).

Burned Area: MODIS MCD64A1 Burned Area (BA) collection 6 (c6) product, accessed from Google Earth Engine (GEE), provides a global monthly burned area at $500 \mathrm{~m}$ spatial resolution, with the dates of burn (i.e., burn date, BD), and per-pixel detection confidence. BD is a data layer characterising the day-of-year (DOY) of burns. The MCD64A1 c6 algorithm is an improvement of Collection 5.1 MCD64A1 and Collection 5.1 MCD45A1 mapping algorithms, thus provides an enhanced detection rate for small burns, reduced temporal uncertainty, and reduced extent of unmapped areas (Giglio et al., 2018; Humber et al., 2019).

Active Fires: MODIS Fire Location (MCD14ML) product characterises the spatial locations, i.e., centroids of 1-km pixels of daily, i.e., 24-h, active fires at the time of Terra and Aqua satellites overpass based on the c6 algorithm (Giglio et al., 2003; Wooster et al., 2003; Wooster et al., 2012; Giglio et al., 2016). The MCD14ML c6 algorithm classifies one or more fires burning actively, at the time of overpass, using MODIS thermal infrared bands centered at $4 \mu \mathrm{m}, 11 \mu \mathrm{m}$, and $12 \mu \mathrm{m}$ and reflectance bands centered at $0.65 \mu \mathrm{m}, 0.86 \mu \mathrm{m}$, and $2.1 \mu \mathrm{m}$. The active fires (AF) points with detection confidence $<10 \%$ were removed from the analysis.

Land Cover Type: Land cover type information was derived from the European Space Agency (ESA) Climate Change Initiative - Land Cover (CCI-LC, available from http://maps.elie.ucl.ac.be/CC I/viewer/download.php) data with a spatial resolution $300 \mathrm{~m}$ (Defourny et al., 2017). This data is created from daily reflectance measurements from Advanced Very High Resolution Radiometer (AVHRR), Satellite Pour l'Observation de la Terre Vegetation (SPOT-VGT), Medium Resolution Imaging Spectrometer (MERIS), PROBA-Vegetation (PROBA-V), and Sentinel-3 Ocean and Land Colour Instrument (OLCI). This product is widely used in data-scarce regions such as SSA due to its detailed classes, i.e., 37, based on the United Nations Land Cover Classification System (UN-LCCS), time-series data, and advanced algorithms (Defourny et al., 2017; Kganyago and Shikwambana, 2019). False changes (such as from inter-annual variability) in land cover data are eliminated by backward and forward verification process and detected by the use of multi-sensor and multitemporal data (Bontemps et al., 2013; Li et al., 2018). The 2018 CCI-LC was reclassified into five broad land cover types (see Fig. 1), viz. Forest cover (FC), Cultivated land (CL), Grassland (GL), Shrubland (SL), and other vegetation covers (OV). The classes that do not characterise vegetation were discarded. A summary of the data used in this study is shown in Table 1.

\subsection{Statistical Analysis}

A simple difference and decrease ratio (DR) (Chen et al., 2020) were calculated to determine the differences in fire parameters between the reference year (i.e., 2019) and COVID-19 year 
Table 1. Summary of data products used in the study.

\begin{tabular}{llll}
\hline Sensor(s) & Spatial resolution & Temporal resolution & Products \\
\hline Merra-2 & $0.5^{\circ} \times 0.625^{\circ}$ & Daily & Black Carbon concentration \\
TROPOMI & $0.01 \times 0.01$ arc degrees & 1-day & Cabon Monoxide \\
CALIPSO & $0.5^{\circ} \times 0.625^{\circ}$ & Monthly & Smoke and Polluted dust AOD 532 nm \\
MODIS & $500 \mathrm{~m}$ & Monthly & Burned Area (MCD64A1) \\
& $1 \mathrm{~km}$ & Daily & AOD (550 nm) \\
MODIS & $1 \mathrm{~km}$ & Daily & Fire Location (MCD14ML) \\
PROBA-V, Sentinel-3 OLCI & $300 \mathrm{~m}$ & Annual & Land Cover (CCI-LC) \\
\hline
\end{tabular}

(i.e., 2020) and the degree of decrease in these parameters as a result of COVID-19 lockdown (Eq. (1)), respectively.

$D R_{i}=\frac{1-x_{t 2}}{x_{t 1}}$

where: $D R_{i}$ is the DR for parameter $i$, and $x_{t 2}$ and $x_{t 1}$ indicate the total or mean for the fire parameter at $t 2$, i.e., 2020 and $t 1$, i.e., 2019 , respectively.

Pearson correlation analysis, $r$, was performed to determine the relationship between emissions and burned area (BA).

\section{RESULTS AND DISCUSSION}

\subsection{Changes in Biomass Emissions during COVID-19 Lockdown}

In this section, we analyse the spatial distribution of $\mathrm{CO}, \mathrm{BC}$, and smoke emitted during wildfires. Crutzen and Carmichael (1993) note that biomass burning is perceived as the most significant source of $\mathrm{CO}$. Therefore, $\mathrm{CO}$ can be used as an indicator to estimate the severity of biomass burning in any area. For example, the burning of dense vegetation would result in high $\mathrm{CO}$ emissions compared to sparse vegetation. Fig. 2 shows the spatial distribution of $\mathrm{CO}$ due to fires in the SSA region before and during the lockdown period. During the period 01 February-26 March 2020 (see Fig. 2(d)), intense plumes of CO $\left(\sim 0.045 \mathrm{~mol} \mathrm{~m}^{-2}\right)$ were observed in northern and southern SSA region between $5^{\circ} \mathrm{S}$ and $10^{\circ} \mathrm{N}$. These plumes are attributed to the biomass burning activities that include forest and maquis fires and the burning of agricultural wastes (Bilonda, 2020). Other CO contributing emission sources include domestic fires and motor vehicle emissions (Kganyago and Shikwambana, 2019). However, motor vehicle emissions are expected to be low due to lockdown restrictions of mobility. During the 27 March 30 April (see Fig. 2(e)) and 01 May-31 May 2020 (see Fig. 2(f)), there was a slight decrease in CO emissions as a result of decreased fire events in the northern (i.e., $0^{\circ}$ and $\left.15^{\circ} \mathrm{N}\right)$ and southern SSA $\left(\sim 15^{\circ} \mathrm{S}\right)$. Generally, the March-April-May (MAM) constitute the crop harvesting period in the SH of the SSA region; hence, less burning occurs, and lower emissions of CO are expected (Shikwambana, 2019). Comparing the 2019 and 2020 CO emission years using Differences, it was observed that during the lockdown periods, $\mathrm{CO}$ emissions increased by up to $0.008 \mathrm{~mol} / \mathrm{m}^{2}$ in the region between $15^{\circ} \mathrm{S}$ and $15^{\circ} \mathrm{N}$ (see Figs. $2(\mathrm{~g}), 2(\mathrm{~h})$, and $2(\mathrm{i})$ ). This result means that there were more fires and burned fuel (i.e., vegetation) in the year 2020 compared to the year 2019 during the same period; thus, releasing more $\mathrm{CO}$. The increase coincides with the results in Fig. 6 , showing an increase in the burned area. A large increase in the CO emissions is mainly observed in the 01 May-31 May period in central Africa, particularly in the Democratic Republic of the Congo (DRC), Equatorial Guinea, and Gabon. The increase of $\mathrm{CO}$ in these countries is due to the availability of high fuel amounts, mainly forests, that burned extensively at multiple locations (see Figs. 1, 6, and 8).

Even though BC emissions measurements are highly uncertain (Sullivan et al., 2017), a noticeable increase in $\mathrm{BC}$ concentration differences is observed in Fig. 3(i). Uncertainties in the $\mathrm{BC}$ estimates can become large due to the variability of biomass burning emissions, resulting in the overestimation of BC concentration. Generally, BC aerosols are formed from incomplete 

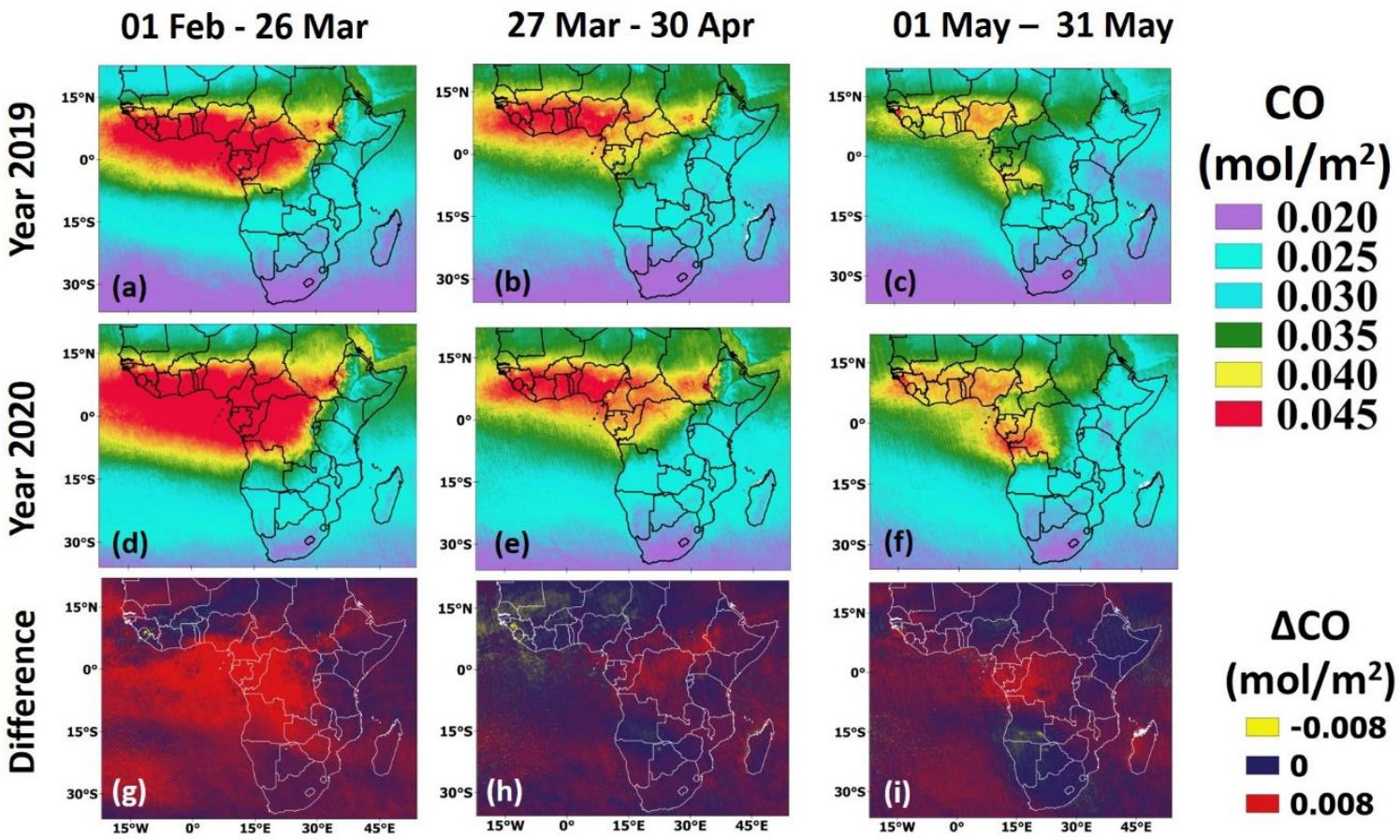

Fig. 2. CO over SSA before and during the lockdown and CO differences between COVID-19 year (2020) and reference year (2019).
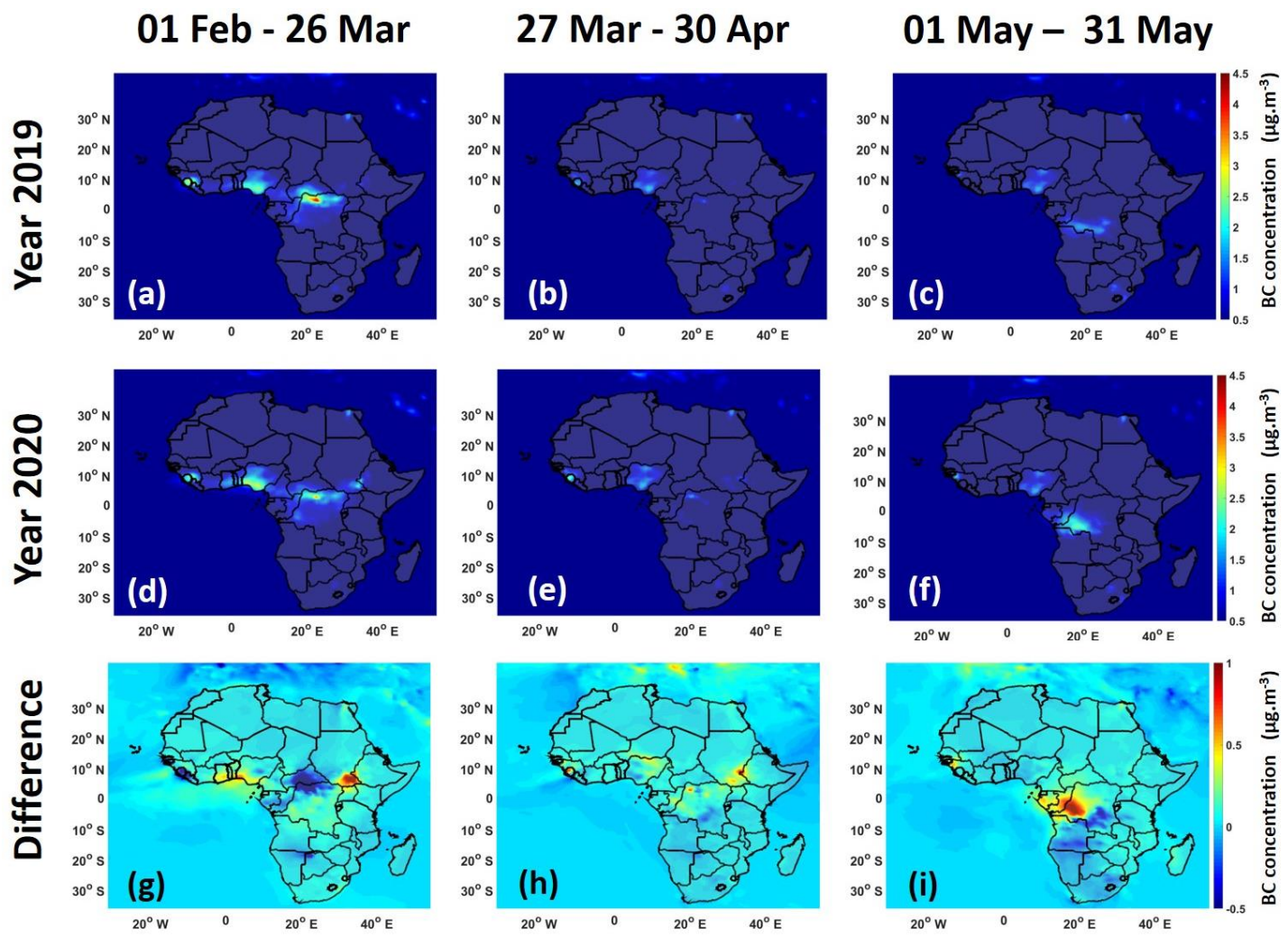

Fig. 3. BC over SSA before and during the lockdown and BC differences between COVID-19 year (2020) and reference year (2019).

combustion of fossil fuels, biofuel, and biomass burning. Therefore, the observed anomalous BC concentration in May 2020 (Fig. 3(i)) has resulted from the COVID-19 lockdown. Again, the burning of land for planting could be the primary reason for the increase in $\mathrm{BC}$ concentration. It has been shown that fires are used as a land management tool to improve soils and inhibit invasive plant 
spread (Santín and Doerr, 2016). Núñez et al. (2014) further state that the co-emission ratio of $\mathrm{BC}$ to organic carbon varies by vegetation type, combustion efficiency, and the extent of emission controls. Hence, BC generally tends to form in significant amounts. A recent study by Shikwambana (2020) also shows that emissions from the DRC are four times the concentration of South Africa. Additionally, BC and CO are products of incomplete combustion of carbon-based fuels. However their emission ratios differ significantly for different sources. Therefore, the differences in measured ratios can indicate the presence of different sources (Bond et al., 2004).

The smoke+polluted dust AOD observations from CALIOP (see Fig. 4) fully complement the observations from the $\mathrm{CO}$ and $\mathrm{BC}$ distribution. Smoke+polluted dust emissions are related to wildfires (Shikwambana and Sivakumar, 2018). High values of AOD (i.e., 0.25) were observed in central Africa in April. In agreement, the Difference in April showed an increase in the smoke+polluted dust by $\sim 20 \%$. Therefore, the Difference for smoke+polluted dust in April (Fig. 4(f)) confirms that there were more burnings during COVID-19 lockdown in 2020 than usual. Although fires are influenced by complex factors such as topography, vegetation, and meteorological conditions (Estes et al., 2017; Turco et al., 2017), the analysis in this study suggests the influence of the lockdown restrictions as changes in emissions (i.e., increase) corresponded to the lockdown period. Kganyago and Shikwambana (2019) showed that the MAM period in SSA (i.e., corresponding to lockdown periods studied here) is characterised by the lowest emissions of $\mathrm{CO}, \mathrm{BC}$, and smoke in the SSA region, as it constitutes the transitional period from the $\mathrm{NH}$ fire season during DecemberJanuary-February (DJF) to SH fire season in June-July-August (JJA). Therefore, the observed increase can be attributed to unattended fires due to the closure of wildfire management and
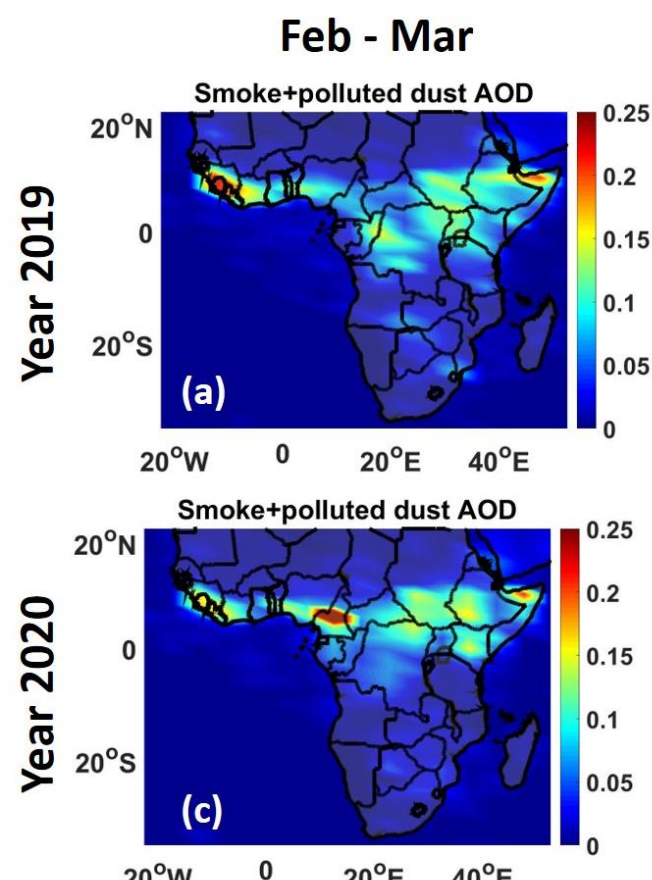

$20^{\circ} \mathrm{W} \quad 0 \quad 20^{\circ} \mathrm{E} \quad 40^{\circ} \mathrm{E}$

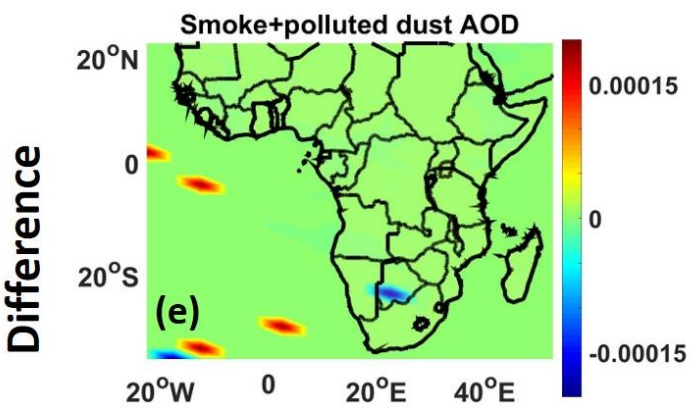

Apr
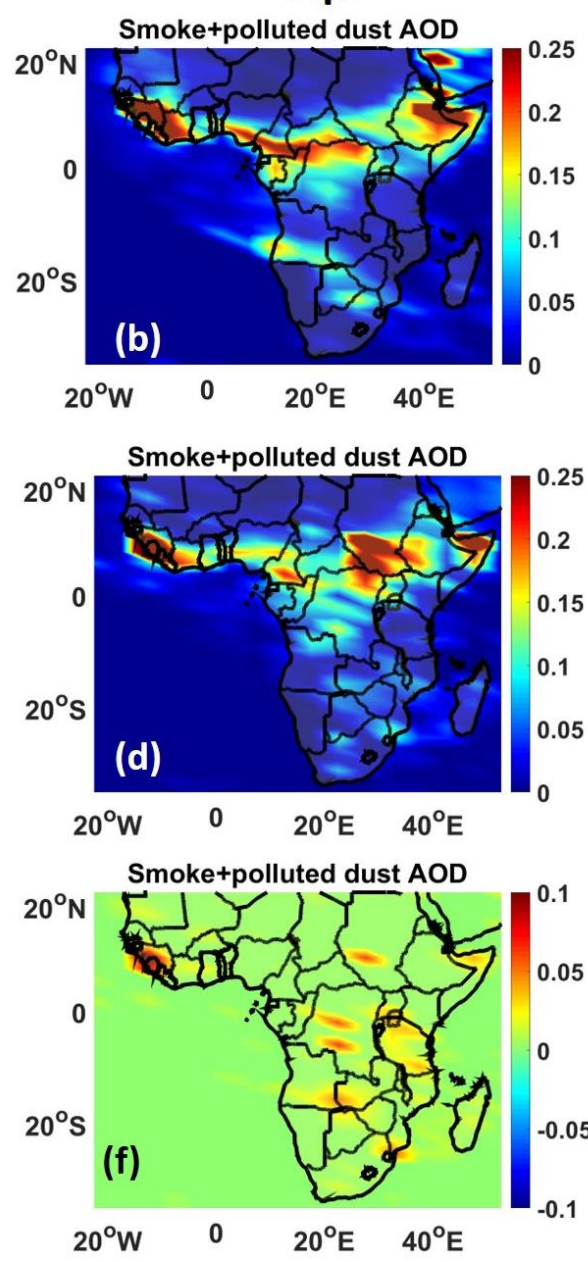

Fig. 4. Smoke+polluted dust AOD over SSA before and during the lockdown and the smoke+polluted dust AOD differences between COVID-19 year (2020) and reference year (2019). 
control agencies during the lockdown periods. The increasing emissions found here have implications for public health since most African communities and cities are near the wilderness. Therefore, the condition of COVID-19 patients may be aggravated as a result of polluted air.

Aerosol optical depth (AOD) is a variable used to assess the aerosol load (i.e., smoke particles, desert dust, sea salt, and urban haze) in the atmosphere. AOD is used to reflect aerosol column loading. However, the disadvantage of AOD is that it lacks to distinguish between aerosol types. The spatial distribution of AOD in the SSA region is shown in Fig. 5. The dominance of AOD (AOD $=1.2$ ) is observed in the latitude of between $0^{\circ}-12^{\circ} \mathrm{N}$ (Figs. $5(\mathrm{a})-5(\mathrm{f})$ ). In this region, the dominating aerosols are likely to be smoke particles, urban haze particles, and dust. The Differences in the period of 01 February-26 March (see Fig. 5(g)) shows an increase in AOD. The major contributor of AOD is from smoke particles during biomass burning. Minor contribution of $A O D$ is from dust from the nearby deserts and urban haze from industrial emissions. The 27 March-30 April period (see Fig. 5(h)) shows a decrease in AOD, indicating fewer fires during this period in the $0^{\circ}-12^{\circ} \mathrm{N}$ region. This agrees with the observations from Figs. $2(\mathrm{~h})$ and $3(\mathrm{~h})$, which show the distribution of $\mathrm{CO}$ and $\mathrm{BC}$, respectively. The calculated Difference for 01-31 May has no data for the region $0^{\circ}-12^{\circ} \mathrm{N}$. Nevertheless, high AOD values (between $0.8-1.2$ ) in the region $10^{\circ} \mathrm{N}-14^{\circ} \mathrm{N}$ are observed. These are dust aerosols from the Sahara Desert. To further confirm the observed emissions, we analysed the amount of burned area (BA), burned land cover types, and AF density during lockdown periods, as detailed below.

\subsection{Changes in Fire Characteristics during COVID-19 Lockdown}

We analysed the change in the burned area (BA) before and during the lockdown using data from the MODIS MCD64A1 product. Fig. 6 shows the changes in BA in the SSA region during the COVID-19 lockdown. Fig. 6(a) shows a comparison of daily fluctuations in BA for the reference year (i.e., 2019), 5-Year Mean (2015-2019), and COVID-19 year (i.e., 2020), while Fig. 6(b) indicates the Differences and decrease ratio (DR) for BA. During period 01 February-26 March (i.e., before lockdown), the BA was high in both 2019 and 2020, while the 5-Year Mean shows relatively low BA. However, it was dropping considerably (for all the years) due to the end of the
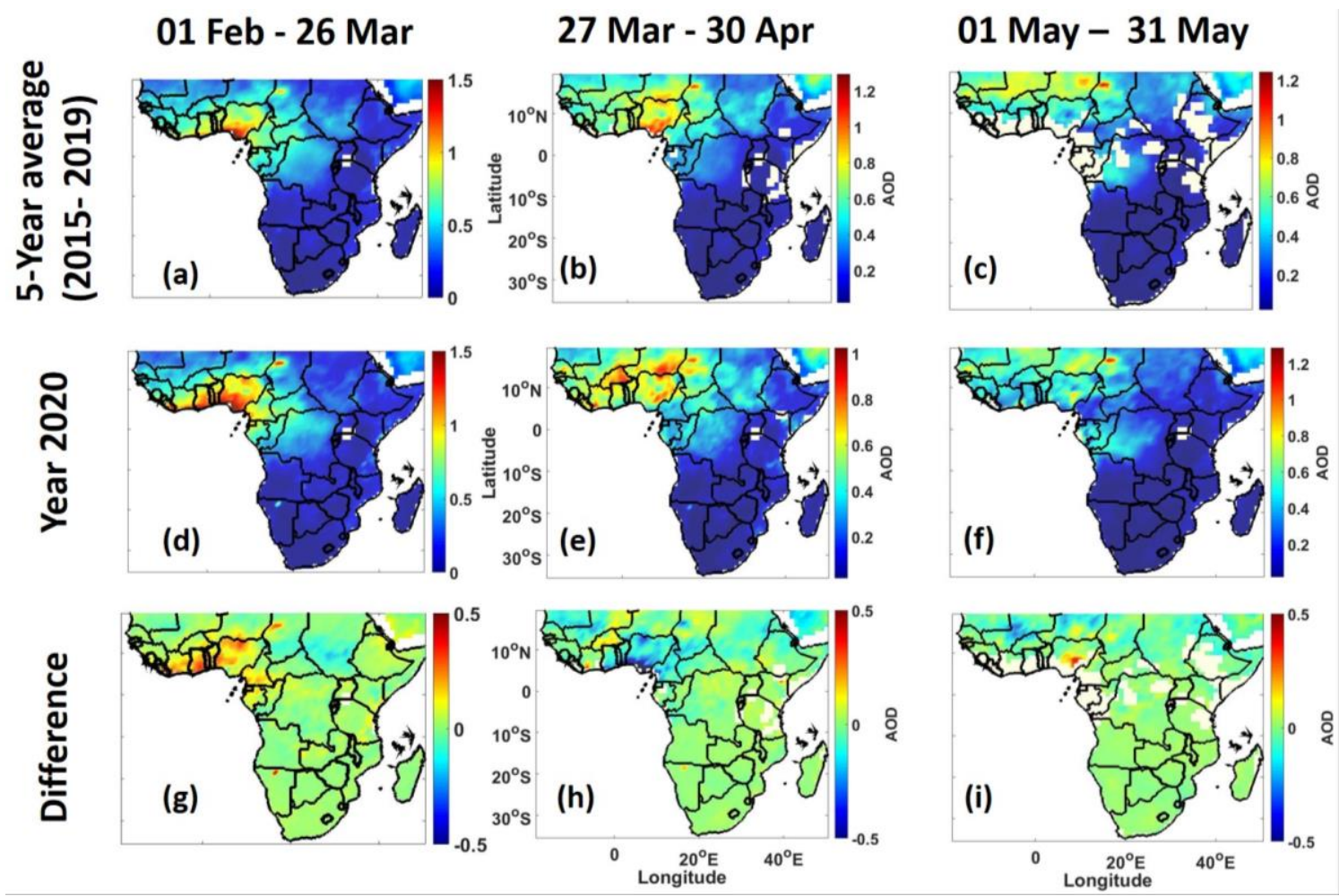

Fig. 5. AOD over SSA before and during the lockdown and AOD differences between COVID-19 year (2020) and 5-year average (2015-2019). 
(a)

을

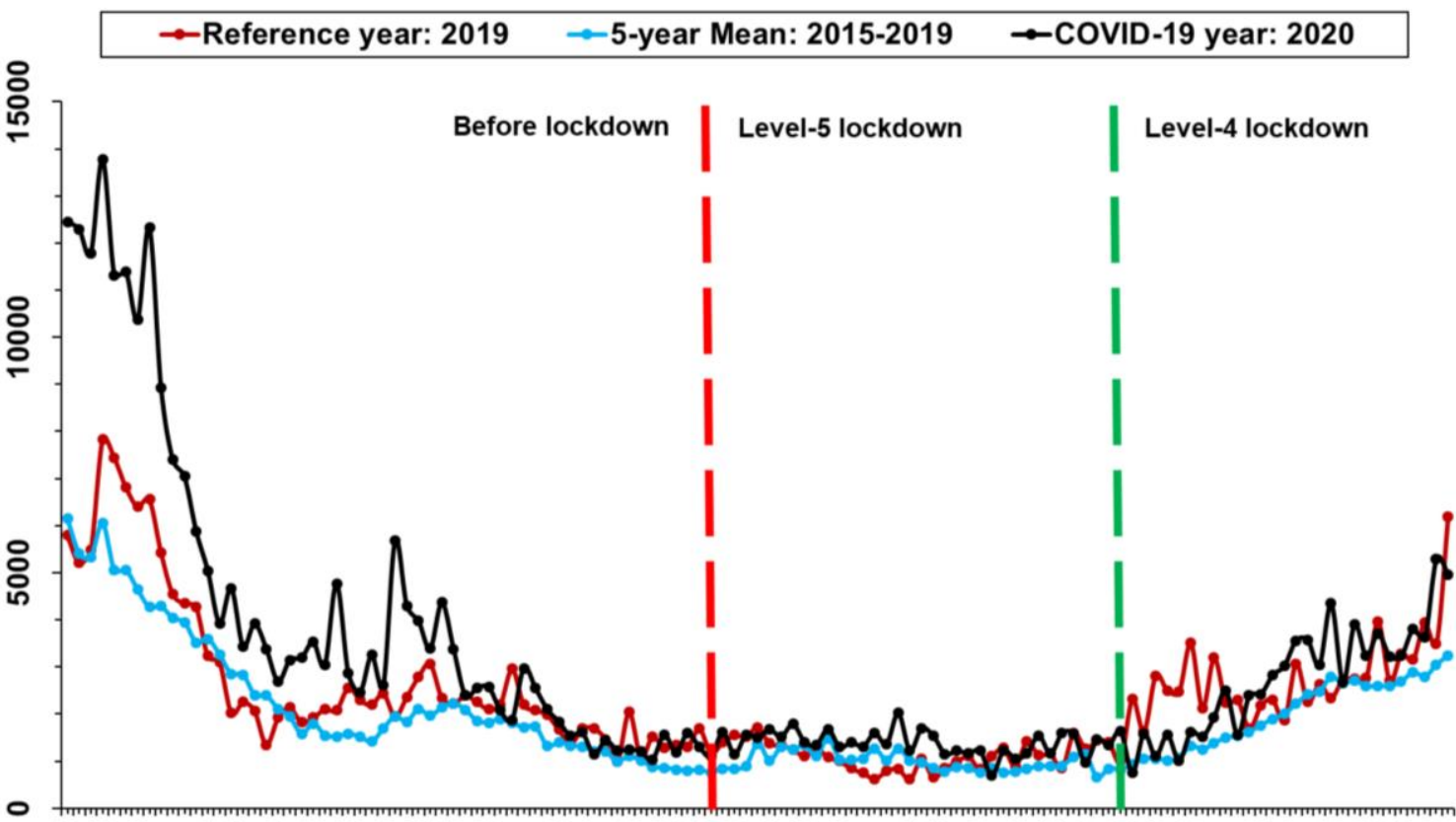

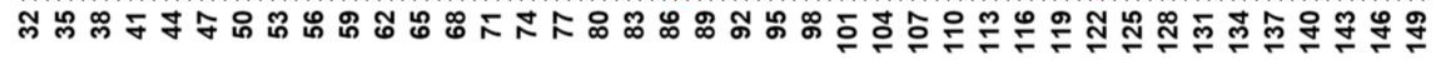
Day-of-Year (DOY)

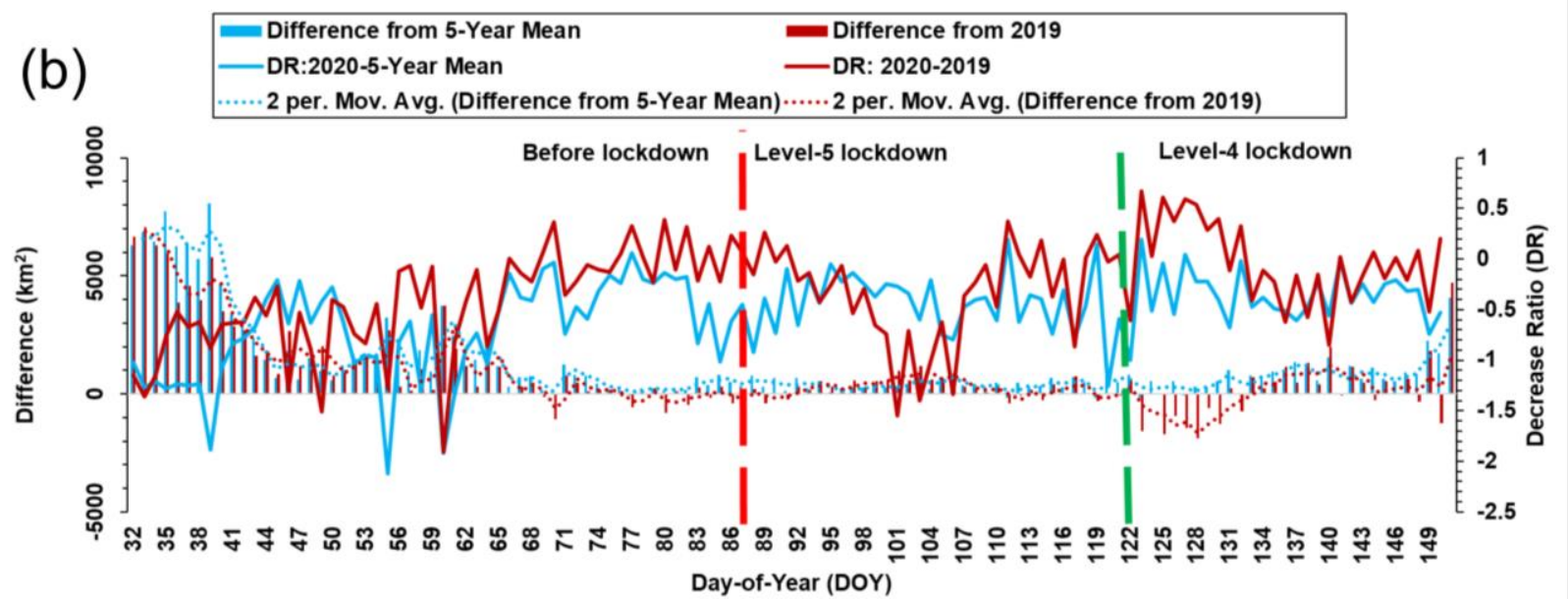

Fig. 6. Daily change in the burned area (BA) at three periods: before lockdown (i.e., 01 February-31 March), Level-5 lockdown (i.e., 27 March-30 April), and Level-4 lockdown (i.e., 01 May-31 May): (a) temporal variations in BA, and (b) the absolute Difference (DR) and decrease ratio (DR) in BA between 2019 and 2020.

fire season in the NH of the SSA region (Zubkova et al., 2019). During the period 27 March-30 April (i.e., level 5 lockdown), the BA was the lowest (i.e., $<200 \mathrm{~km}^{2}$ ) in all the years. This observation is consistent with what was reported by Kganyago and Shikwambana (2019), who found the lowest BA and burn frequency $(<20 \%)$ during the MAM period in the entire SSA region for nine years. However, the BA during the COVID-19 year (i.e., 2020) was slightly higher when compared to both 2019 (i.e., DR -1.5) and the 5-Year Mean (i.e., DR -0.1). Finally, during 01 May-30 May period, the BA started increasing, with 2020 lower than in 2019 (DR = 0.5), and later, BA becomes higher in 2020 than 2019 ( $D R=-1$ ). This observation is consistent with the results for fire emissions (i.e., $\mathrm{CO}, \mathrm{BC}$, and smoke+polluted dust $\mathrm{AOD}$ presented in Figs. 2-4). The $B A$ in 2020 was also slightly higher than the 5 -Year Mean (DR $=-0.5$ ).

The association between BA and CO and between BA and UV aerosol index (UVAI) is shown in Figs. 7(a) and 7(b), respectively. A moderate positive correlation between $\mathrm{BA}$ and $\mathrm{CO}(r=0.49)$ is observed in Fig. 7(a). This means that as BA increases, $\mathrm{CO}$ emissions also increase. Furthermore, a strong positive correlation ( $r=0.61)$ between BA and UVAI is observed in Fig. $7(b)$. The UVAI 

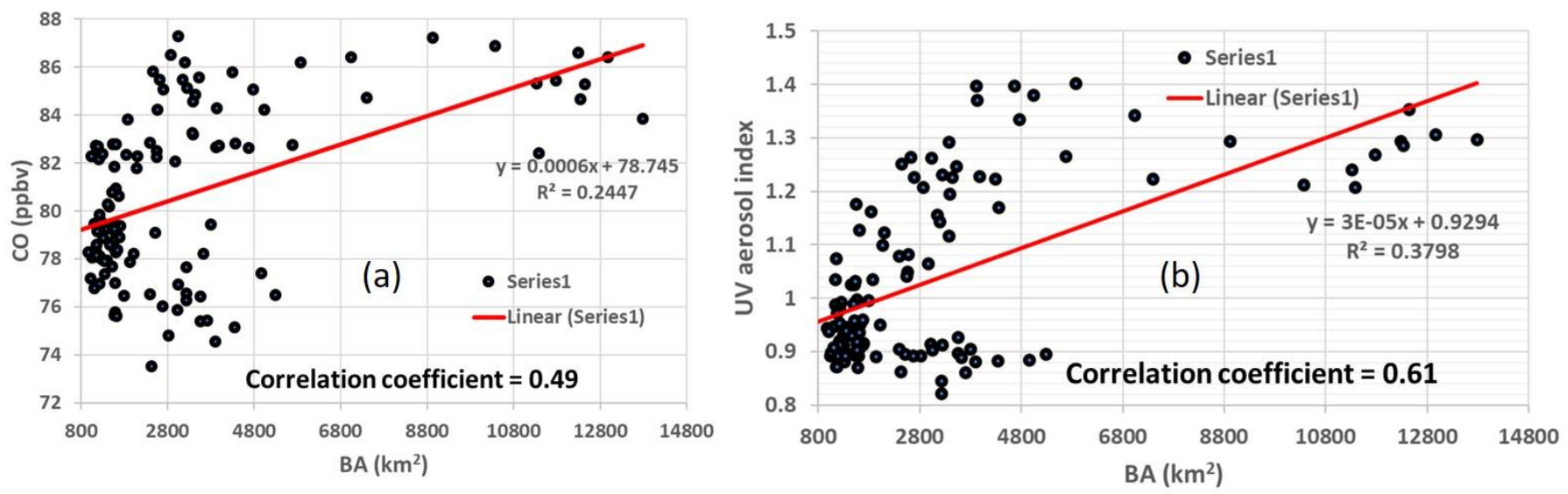

Fig. 7. Scatter plots for (a) BA and CO and (b) BA and UV aerosol index.

detects the presence of UV-absorbing aerosols such as dust and soot (which comes from incomplete combustion of a carbon-based material). Therefore, it can be deduced that the increase in BA increased the soot. These results support the fact that there was an increase in biomass burning during the lockdown period in the SSA region.

The wildfires affected various land cover types, as shown in Fig. 8. Specifically, the BA was considerably higher over $\mathrm{CL}$ and $\mathrm{FC}$ at period 01 February-26 March (i.e., before lockdown), and over SL and FC during 27 March-30 April period (i.e., Level-5 lockdown), and CL during 01 May30 May 2020 (i.e., Level-4 lockdown). In contrast, GL was consistently lower in 2020 at all considered periods (i.e., before and during lockdown), while FC was lower in the period 01 May30 May 2020 (i.e., Level-4 lockdown). The clearing of land by burning FC and SL is well established in the literature (Varma, 2003; Stellmes et al., 2013; Schneibel et al., 2017); thus, not surprising in this study. For example, Schneibel et al. (2017) found that deforestation of Miombo forests in Angola was driven by fires mainly occurring in the areas close to agricultural areas, villages, and roads. In another study, Stellmes et al. (2013) found that thornbush savannahs and grasslands in the upper catchment of the Okavango region were mostly affected by fires. A recent study conducted across the SSA region (Kganyago and Shikwambana, 2019) found that fires during the MAM period were dominated by the burning of Broadleaved deciduous trees, Shrublands, and Rainfed croplands. This is consistent with the results found in this study. For emissions, the results imply more prolonged emissions of $\mathrm{CO}$ (Fig. 2) and smoke+polluted dust (Fig. 4) as a result of the burning of high biomass land cover types such as FC and SL, which consist of leaves, twigs, and woody branches and stems. Incomplete combustion of these cover types, led to an increase in $\mathrm{BC}$ emissions, as observed in Fig. 3.

Fig. 9 shows the density of the active fires (i.e., the number of fires per $0.1^{\circ}$ pixel) detected by MODIS MCD14ML product. Generally, the results show similar trends to BA and correspond to the distribution of $\mathrm{CO}, \mathrm{BC}$, and smoke+polluted dust AOD. Higher fire density in 2020 is evident from Fig. 9 as compared to 2019. During the lockdown period, i.e., 27 March-31 May, the fires were mainly concentrated over the central SSA region (i.e., Democratic Republic of Congo - DRC and Angola) and western SSA region (i.e., Guinea, Côte d'Ivoire, and Liberia). The discrepancy between the BA and fire density results can be attributed to the omission of small burns by MODIS as reported previously (Randerson et al., 2012; Padilla et al., 2014; Roteta et al., 2019; Kganyago and Shikwambana, 2020). Other non-negligent fire densities can be observed during Level-5 lockdown (i.e., 27 March-30 April) in countries such as Sudan and Ethiopia located in the north-east and Zambia, Madagascar, and South Africa located in the south. It is anticipated that due to lockdown restrictions, the fire management and control offices were closed; thus, this allowed fires - which may have originated from croplands - to spread widely and several fires to ignite as influenced by the wind speed and direction, vegetation conditions, topography, temperatures, relative humidity, and precipitation. The results of the number of fires and burned areas are expected to be underestimated due to MODIS coarse spatial resolution, i.e., $1 \mathrm{~km}$ and $500 \mathrm{~m}$, respectively (Schroeder et al., 2014; Oliva and Schroeder, 2015). In the future, AF data from Visible Infrared Imaging Radiometer Suite (VIIRS) at $375 \mathrm{~m}$ should be explored. 
(a)

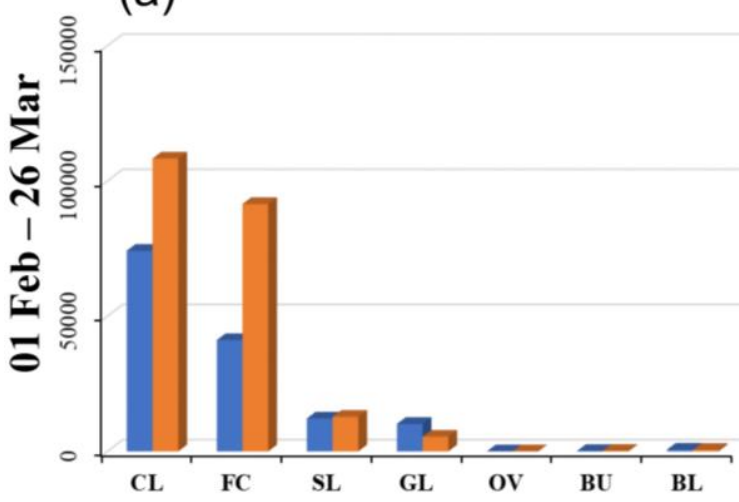

(b)

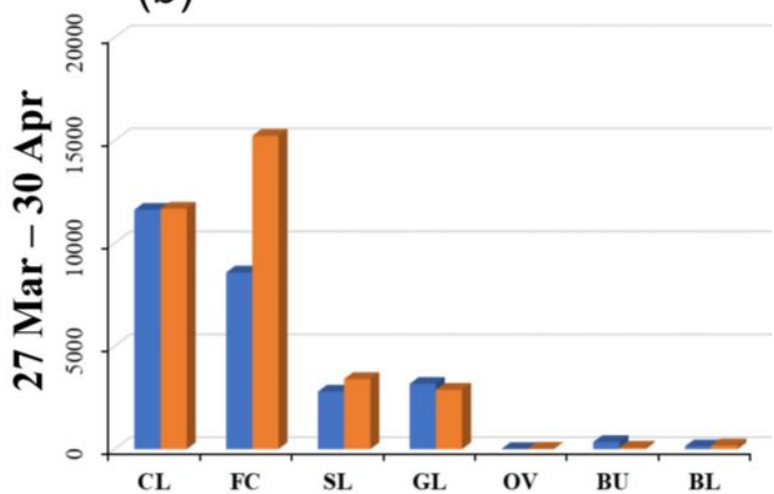

(c) $\quad=2019=2020$

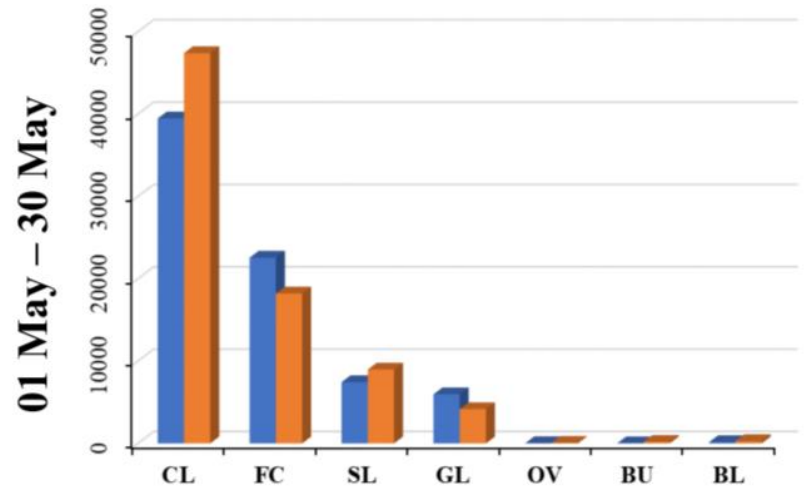

Fig. 8. Burned land cover types at three periods: before lockdown (i.e., 01 February-31 March), Level-5 lockdown (i.e., 27 March30 April), and Level-4 lockdown (i.e., 01 May-31 May) in 2019 and 2020.

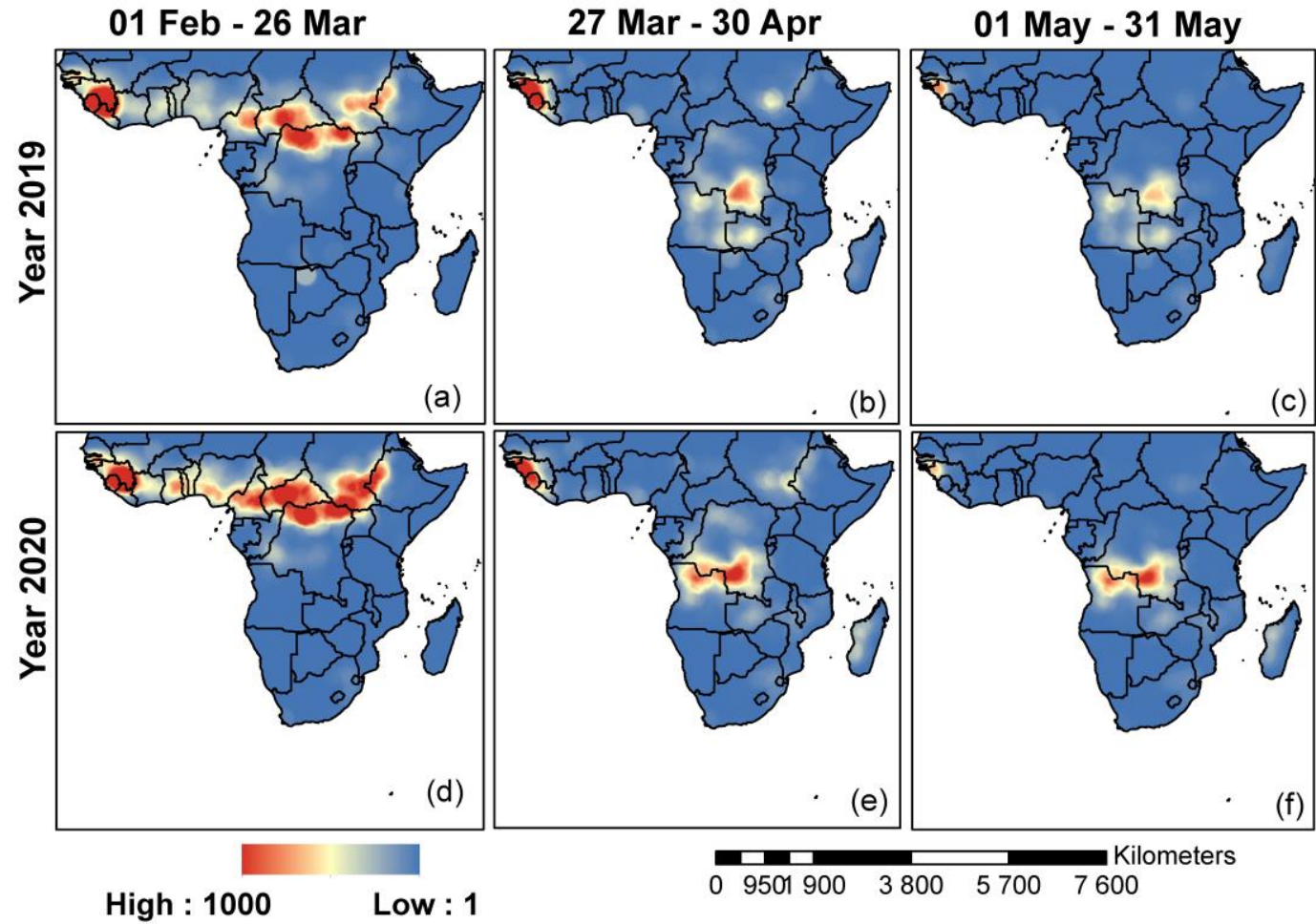

Fig. 9. Fire density at three periods: before lockdown (i.e., 01 February-31 March), Level-5 lockdown (i.e., 27 March-30 April), and Level-4 lockdown (i.e., 01 May-31 May) in 2019 and 2020. 
This study analysed the effect of COVID-19 lockdown on biomass burning emissions by assessing the changes in emissions (i.e., $\mathrm{CO}, \mathrm{BC}$, smoke+polluted dust $\mathrm{AOD}$ ) and fire characteristics (i.e., BA, AF) between the reference year, i.e., 2019 and COVID-19 year, i.e., 2020. The results indicate increased emissions during the lockdown period due to the burning of forests, shrublands, and cultivated lands. The use of fires as a land management tool in Africa, i.e., for eradicating invasive species, clearing lands for agricultural expansion, and land preparation, is well known. However, the 2020 emissions, BA, and fire density were higher than the previous year (i.e., 2019). Although this increase can be attributed to suitable meteorological and vegetation conditions which are generally known to influence fires patterns - the effect of COVID-19 lockdown cannot be ruled out. This is especially true for Africa, where the majority of fires are anthropogenic. The proximity of natural vegetation to cultivated lands may have resulted in a large BA over FC and $\mathrm{SL}$, which resulted in prolonged emissions due to their high biomass. Therefore, it is anticipated that under lockdown restrictions, the fires ignited and propagated in many areas without human interference (i.e., suppression) since fire authorities were either closed (i.e., during Level-5 lockdown) or not operating at full capacity (i.e., during Level-4 lockdown). This study was limited by the unavailability of smoke+polluted dust AOD data during the period 01 May-31 May, MODIS spatial resolution, which missed small fires and burns, and lack of public health data to correlate with satellite measurements. In the future, these aspects should be considered in more detail. Nevertheless, results from this study have implications for ambient air quality and public health, especially for COVID-19 patients in African cities located near the wilderness and agricultural areas.

\section{ACKNOWLEDGMENTS}

The authors wish to thank the South African National Space Agency for providing resources for this study. We appreciate the Sentinel-5 P/TROPOMI Carbon monoxide (CO) products provided by the European Space Agency (ESA), and MODIS burned area (BA), active fires (AF), and MERRA2 Black carbon (BC) products provided by the National Aeronautics and Space Administration (NASA). We appreciate anonymous reviewers and editors for their constructive feedback that contributed to the quality of this manuscript.

\section{DISCLAIMER}

The authors declare that there are no financial and personal interests that influenced the results and work presented in the manuscript.

\section{REFERENCES}

Allen, E.B., Steers, R.J., Dickens, S.J. (2011). Impacts of fire and invasive species on desert soil ecology. Rangeland Ecol. Manage. 64, 450-462. https://doi.org/10.2111/REM-D-09-00159.1

Andela, N., Van Der Werf, G.R. (2014). Recent trends in African fires driven by cropland expansion and El Niño to La Niña transition. Nat. Clim. Change 4, 791-795. https://doi.org/10.1038/nclim ate2313

Archibald, S. (2016). Managing the human component of fire regimes: lessons from Africa. Philos. Trans. R. Soc. London, Ser. B 371, 20150346. https://doi.org/10.1098/rstb.2015.0346

Baldasano, J.M. (2020). COVID-19 lockdown effects on air quality by $\mathrm{NO}_{2}$ in the cities of Barcelona and Madrid (Spain). Sci. Total Environ. 741, 140353. https://doi.org/10.1016/j.scitotenv.2020. 140353

Bilonda, M.K. (2020). Burning of Biomass in the Democratic Republic of Congo, in: Mammino, L. (Ed.), Biomass Burning in Sub-Saharan Africa: Chemical Issues and Action Outreach, Springer Netherlands, Dordrecht, pp. 57-70. https://doi.org/10.1007/978-94-007-0808-2_5

Bond, T.C., Streets, D.G., Yarber, K.F., Nelson, S.M., Woo, J.H., Klimont, Z. (2004). A technology- 
based global inventory of black and organic carbon emissions from combustion. J. Geophys. Res. 109, D14203. https://doi.org/10.1029/2003JD003697

Bontemps, S., Defourny, P., Radoux, J., Van Bogaert, E., Lamarche, C., Achard, F., Mayaux, P., Boettcher, M., Brockmann, C., Kirches, G. (2013). Proceedings of the ESA living planet symposium. Edimburgh, pp. 9-13.

Boschetti, L., Roy, D.P. (2008). Defining a fire year for reporting and analysis of global interannual fire variability. J. Geophys. Res. 113, G03020. https://doi.org/10.1029/2008JG000686

Buchard, V., da Silva, A., Colarco, P., Darmenov, A., Randles, C., Govindaraju, R., Torres, O., Campbell, J., Spurr, R. (2015). Using the OMI aerosol index and absorption aerosol optical depth to evaluate the NASA MERRA Aerosol Reanalysis. Atmos. Chem. Phys. 15, 5743. https://doi.org/10.5194/acp-15-5743-2015

Buchard, V., Da Silva, A., Randles, C., Colarco, P., Ferrare, R., Hair, J., Hostetler, C., Tackett, J., Winker, D. (2016). Evaluation of the surface PM 2.5 in Version 1 of the NASA MERRA Aerosol Reanalysis over the United States. Atmos. Environ. 125, 100-111. https://doi.org/10.1016/j.at mosenv.2015.11.004

Burgess, N., Hales, J.A., Underwood, E., Dinerstein, E., Olson, D., Itoua, I., Schipper, J., Ricketts, T., Newman, K. (2004). Terrestrial ecoregions of africa and madagascar: A conservation assessment. Island Press.

Chen, Q.X., Huang, C.L., Yuan, Y., Tan, H.P. (2020). Influence of COVID-19 event on air quality and their association in mainland China. Aerosol Air Qual. Res. 20, 1541-1551. https://doi.org/10.4 209/aaqr.2020.05.0224

Cheng, V.C.., Wong, S.C., Chuang, V.W., So, S.Y.., Chen, J.H.., Sridhar, S., To, K.K.., Chan, J.F.., Hung, I.F.., Ho, P.L., Yuen, K.Y. (2020). The role of community-wide wearing of face mask for control of coronavirus disease 2019 (COVID-19) epidemic due to SARS-CoV-2. J. Infect. 81, 107-114. https://doi.org/10.1016/j.jinf.2020.04.024

Crutzen, P., Carmichael, G. (1993). Modeling the influence of fires on atmospheric chemistry. Fire in the environment: The ecological, atmospheric, and climatic importance of vegetation fires. Wiley, pp. 89-105.

Davies, G.M., Pollard, L., Mwenda, M.D. (2010). Perceptions of land-degradation, forest restoration and fire management: A case study from Malawi. Land Degrad Dev. 21, 546-556. https://doi.org/10.1002/ldr.995

De Sales, F., Xue, Y., Okin, G.S. (2016). Impact of burned areas on the northern African seasonal climate from the perspective of regional modeling. Clim. Dyn. 47, 3393-3413. https://doi.org/ 10.1007/s00382-015-2522-4

Defourny, P., Brockmann, C., Bontemps, S., Lamarche, C., Santoro, M., Boettcher, M., Wevers, J. (2017). CCI-LC URD Phase II. Land Cover Climate Change Initiative - Product User Guide v2.

Estes, B.L., Knapp, E.E., Skinner, C.N., Miller, J.D., Preisler, H.K. (2017). Factors influencing fire severity under moderate burning conditions in the Klamath Mountains, northern California, USA. Ecosphere 8, e01794. https://doi.org/10.1002/ecs2.1794

Esteves, T., Kirkby, M., Shakesby, R., Ferreira, A., Soares, J., Irvine, B., Ferreira, C., Coelho, C., Bento, C., Carreiras, M. (2012). Mitigating land degradation caused by wildfire: Application of the PESERA model to fire-affected sites in central Portugal. Geoderma 191, 40-50. https://doi.org/10.1016/j.geoderma.2012.01.001

Gelaro, R., McCarty, W., Suárez, M.J., Todling, R., Molod, A., Takacs, L., Randles, C.A., Darmenov, A., Bosilovich, M.G., Reichle, R. (2017). The modern-era retrospective analysis for research and applications, version 2 (MERRA-2). J. Clim. 30, 5419-5454. https://doi.org/10.1175/JCLI-D-160758.1

Giglio, L., Boschetti, L., Roy, D.P., Humber, M.L., Justice, C.O. (2018). The Collection 6 MODIS burned area mapping algorithm and product. Remote Sens. Environ. 217, 72-85. https://doi.org/10.1016/j.rse.2018.08.005

Giglio, L., Descloitres, J., Justice, C.O., Kaufman, Y.J. (2003). An enhanced contextual fire detection algorithm for MODIS. Remote Sens. Environ. 87, 273-282. https://doi.org/10.1016/S00344257(03)00184-6

Giglio, L., Randerson, J.T., van der Werf, G.R. (2013). Analysis of daily, monthly, and annual burned area using the fourth-generation global fire emissions database (GFED4). J. Geophys. Res. 118, 317-328. https://doi.org/10.1002/jgrg.20042 
Giglio, L., Schroeder, W., Justice, C.O. (2016). The collection 6 MODIS active fire detection algorithm and fire products. Remote Sens. Environ. 178, 31-41. https://doi.org/10.1016/j.rse. 2016.02.054

Giles, C., Mwai, P. (2020). Coronavirus: Infections rising amid economic downturn in Africa, https://www.bbc.com/news/world-africa-52395976 (accessed 26 July 2020).

Guo, Y.R., Cao, Q.D., Hong, Z.S., Tan, Y.Y., Chen, S.D., Jin, H.J., Tan, K.S., Wang, D.Y., Yan, Y. (2020). The origin, transmission and clinical therapies on coronavirus disease 2019 (COVID-19) outbreak - An update on the status. Mil. Med. Res. 7, 11. https://doi.org/10.1186/s40779-02000240-0

Humber, M.L., Boschetti, L., Giglio, L., Justice, C.O. (2019). Spatial and temporal intercomparison of four global burned area products. Int. J. Digital Earth 12, 460-484. https://doi.org/10.1080/ 17538947.2018.1433727

Ialongo, I., Virta, H., Eskes, H., Hovila, J., Douros, J. (2020). Comparison of TROPOMI/Sentinel-5 Precursor $\mathrm{NO}_{2}$ observations with ground-based measurements in Helsinki. Atmos. Meas. Tech. 13, 205-218. https://doi.org/10.5194/amt-13-205-2020

Ite, A.E., Ibok, U.J. (2013). Gas flaring and venting associated with petroleum exploration and production in the Nigeria's Niger delta. Am. J. Environ. Prot. 1, 70-77. https://doi.org/10.1269 1/env-1-4-1

Jacob, L., Tully, M.A., Barnett, Y.A., López Sánchez, G.F., Butler, L.T., Schuch, F.B., López-Bueno, R., McDermott, D.T., Firth, J., Grabovac, I. (2020). The relationship between physical activity and mental health in a sample of the UK public: A cross-sectional study during the implementation of COVID-19 social distancing measures. Ment. Health Phys. Act. 19, 100345. https://doi.org/10.1016/j.mhpa.2020.100345

Kganyago, M., Shikwambana, L. (2019). Assessing spatio-temporal variability of wildfires and their impact on sub-Saharan ecosystems and air quality using multisource remotely sensed data and trend analysis. Sustainability 11, 6811. https://doi.org/10.3390/su11236811

Kganyago, M., Shikwambana, L. (2020). Assessment of the characteristics of recent major wildfires in the USA, Australia and Brazil in 2018-2019 using multi-source satellite products. Remote Sens. 12, 1803. https://doi.org/10.3390/rs12111803

Kim, E.A. (2020). Social distancing and public health guidelines at workplaces in Korea: Responses to coronavirus disease-19. Saf Health Work. 11, 275-283. https://doi.org/10.1016/j.shaw.202 0.07 .006

Kumar, S. (2020). Effect of meteorological parameters on spread of COVID-19 in India and air quality during lockdown. Sci. Total Environ. 745, 141021. https://doi.org/10.1016/j.scitotenv. 2020.141021

Kuwonu, F. (2020). As COVID-19 cases rise, AFRICAN countries grapple with safely easing lockdowns. https://www.un.org/africarenewal/magazine/june-2020/coronavirus/covid-19africa-cases-rise-along-economic-hardship-countries-grapple-safely-easing (accessed 26 July 2020.

Le Page, Y., Oom, D., Silva, J.M., Jönsson, P., Pereira, J.M. (2010). Seasonality of vegetation fires as modified by human action: Observing the deviation from eco-climatic fire regimes. Global Ecol. Biogeogr. 19, 575-588. https://doi.org/10.1111/j.1466-8238.2010.00525.x

Li, W., MacBean, N., Ciais, P., Defourny, P., Lamarche, C., Bontemps, S., Houghton, R.A., Peng, S. (2018). Gross and net land cover changes in the main plant functional types derived from the annual ESA CCl land cover maps (1992-2015). Earth Syst. Sci. Data, 10, 219-234. https://doi.org/10.5194/essd-10-219-2018

Lotfi, M., Hamblin, M.R., Rezaei, N. (2020). COVID-19: Transmission, prevention, and potential therapeutic opportunities. Clin. Chim. Acta 508, 254-266. https://doi.org/10.1016/j.cca.2020. 05.044

Mackenzie, J.S., Smith, D.W. (2020). COVID-19: a novel zoonotic disease caused by a coronavirus from China: What we know and what we don't. Microbiol. Aust. 41, 45-50. https://doi.org/10.1071/MA20013

Menut, L., Bessagnet, B., Siour, G., Mailler, S., Pennel, R., Cholakian, A. (2020). Impact of lockdown measures to combat Covid-19 on air quality over western Europe. Sci. Total Environ. 741, 140426. https://doi.org/10.1016/j.scitotenv.2020.140426

Núñez, X.C., Ruiz, L.V., García, C.G. (2014). Black carbon and organic carbon emissions from 
wildfires in Mexico. Atmosfera 27, 165-172. https://doi.org/10.1016/S0187-6236(14)71107-5

Oliva, P., Schroeder, W. (2015). Assessment of VIIRS $375 \mathrm{~m}$ active fire detection product for direct burned area mapping. Remote Sens. Environ. 160, 144-155. https://doi.org/10.1016/j.rse.201 5.01.010

Olson, D.M., Dinerstein, E., Wikramanayake, E.D., Burgess, N.D., Powell, G.V., Underwood, E.C., D'amico, J.A., Itoua, I., Strand, H.E., Morrison, J.C. (2001). Terrestrial Ecoregions of the World: A New Map of Life on Earth: A new global map of terrestrial ecoregions provides an innovative tool for conserving biodiversity. BioScience 51, 933-938. https://doi.org/10.1641/00063568(2001)051[0933:TEOTWA]2.0.CO;2

Omrani, H., Omrani, B., Parmentier, B., Helbich, M. (2020a). Spatio-temporal data on the air pollutant nitrogen dioxide derived from sentinel satellite for france. Data Brief 28, 105089. https://doi.org/10.1016/j.dib.2019.105089

Otmani, A., Benchrif, A., Tahri, M., Bounakhla, M., El Bouch, M., Krombi, M.h. (2020b). Impact of Covid-19 lockdown on $\mathrm{PM}_{10}, \mathrm{SO}_{2}$ and $\mathrm{NO}_{2}$ concentrations in Salé City (Morocco). Sci. Total Environ. 735, 139541. https://doi.org/10.1016/j.scitotenv.2020.139541

Padilla, M., Stehman, S.V., Litago, J., Chuvieco, E. (2014). Assessing the temporal stability of the accuracy of a time series of burned area products. Remote Sens. 6, 2050-2068. https://doi.org/10.3390/rs6032050

Randerson, J., Chen, Y., Van Der Werf, G., Rogers, B., Morton, D. (2012). Global burned area and biomass burning emissions from small fires. J. Geophys. Res. 117, G04012. https://doi.org/10. 1029/2012JG002128

Rienecker, M.M., Suarez, M., Todling, R., Bacmeister, J., Takacs, L., Liu, H., Gu, W., Sienkiewicz, M., Koster, R., Gelaro, R., Stajner, I., Nielsen, J.E. (2008) The GEOS-5 Data Assimilation System - Documentation of Versions 5.0.1, 5.1.0, and 5.2.0. Technical Report Series on Global Modeling and Data Assimilation, 27. https://gmao.gsfc.nasa.gov/pubs/docs/tm27.pdf

Rienecker, M.M., Suarez, M.J., Gelaro, R., Todling, R., Bacmeister, J., Liu, E., Bosilovich, M.G., Schubert, S.D., Takacs, L., Kim, G.K. (2011). MERRA: NASA's modern-era retrospective analysis for research and applications. J. Clim. 24, 3624-3648. https://doi.org/10.1175/JCLI-D-11 00015.1

Roteta, E., Bastarrika, A., Padilla, M., Storm, T., Chuvieco, E. (2019). Development of a Sentinel-2 burned area algorithm: Generation of a small fire database for sub-Saharan Africa. Remote Sens. Environ. 222, 1-17. https://doi.org/10.1016/j.rse.2018.12.011

Santín, C., Doerr, S.H. (2016). Fire effects on soils: The human dimension. Philos. Trans. R. Soc. London, Ser. B 371, 20150171. https://doi.org/10.1098/rstb.2015.0171

Schneibel, A., Frantz, D., Röder, A., Stellmes, M., Fischer, K., Hill, J. (2017). Using annual landsat time series for the detection of dry forest degradation processes in south-central Angola. Remote Sens. 9, 905. https://doi.org/10.3390/rs9090905

Schroeder, W., Oliva, P., Giglio, L., Csiszar, I.A. (2014). The New VIIRS 375 m active fire detection data product: Algorithm description and initial assessment. Remote Sens. Environ. 143, 85-96. https://doi.org/10.1016/j.rse.2013.12.008

Shikwambana, L., Sivakumar, V. (2018). Global distribution of aerosol optical depth in 2015 using CALIPSO level 3 data. J. Atmos. Sol. Terr. Phys. 173, 150-159. https://doi.org/10.1016/j.jastp.2 018.04.003

Shikwambana, L. (2019). Long-term observation of global black carbon, organic carbon and smoke using CALIPSO and MERRA-2 data. Remote Sens. Lett. 10, 373-380. https://doi.org/10. 1080/2150704X.2018.1557789

Shikwambana, L. (2020). Emissions of toxic gases and aerosols in southern Africa observed during the 2019 JJASO period. Air Qual Atmos Health: 1-10. https://doi.org/10.1007/s11869-02000952-1

Stellmes, M., Frantz, D., Finckh, M., Revermann, R. (2013). Fire frequency, fire seasonality and fire intensity within the Okavango region derived from MODIS fire products. Biodivers Ecol. 5 , 351-362. https://doi.org/10.7809/b-e.00288

Sullivan, R.C., Levy, R.C., da Silva, A.M., Pryor, S.C. (2017). Developing and diagnosing climate change indicators of regional aerosol optical properties. Sci. Rep. 7, 1-13. https://doi.org/10.1 038/s41598-017-18402-x

Theys, N., Hedelt, P., De Smedt, I., Lerot, C., Yu, H., Vlietinck, J., Pedergnana, M., Arellano, S., 
Galle, B., Fernandez, D. (2019). Global monitoring of volcanic $\mathrm{SO}_{2}$ degassing with unprecedented resolution from TROPOMI onboard Sentinel-5 Precursor. Sci. Rep. 9, 1-10. https://doi.org/10. 1038/s41598-019-39279-y

Turco, M., Levin, N., Tessler, N., Saaroni, H. (2017). Recent changes and relations among drought, vegetation and wildfires in the Eastern Mediterranean: The case of Israel. Global Planet. Change 151, 28-35. https://doi.org/10.1016/j.gloplacha.2016.09.002

Van der Werf, G.R., Randerson, J.T., Giglio, L., Collatz, G., Mu, M., Kasibhatla, P.S., Morton, D.C., DeFries, R., Jin, Y., van Leeuwen, T.T. (2010). Global fire emissions and the contribution of deforestation, savanna, forest, agricultural, and peat fires (1997-2009). Atmos. Chem. Phys. 10, 11707-11735. https://doi.org/10.5194/acp-10-11707-2010

Varma, A. (2003). The economics of slash and burn: a case study of the 1997-1998 Indonesian forest fires. Ecol. Econ. 46, 159-171. https://doi.org/10.1016/S0921-8009(03)00139-3

Wilson, J.W., Primack, R.B. (2019). Conservation biology in sub-saharan Africa. Open Book Publishers, Cambridge, UK.

Winker, D., Pelon, J., Coakley Jr, J., Ackerman, S., Charlson, R., Colarco, P., Flamant, P., Fu, Q., Hoff, R., Kittaka, C. (2010). The CALIPSO mission: A global 3d view of aerosols and clouds. Bull. Am. Meteorol. Soc. 91, 1211-1230. https://doi.org/10.1175/2010BAMS3009.1

Winker, D.M., Pelon, J.R., McCormick, M.P. (2003) Lidar Remote Sensing for Industry and Environment Monitoring III, 2003, International Society for Optics and Photonics, pp. 1-11.

Winker, D.M., Vaughan, M.A., Omar, A., Hu, Y., Powell, K.A., Liu, Z., Hunt, W.H., Young, S.A. (2009). Overview of the CALIPSO mission and CALIOP data processing algorithms. J. Atmos. Ocean. Technol. 26, 2310-2323. https://doi.org/10.1175/2009JTECHA1281.1

Wooster, M., Zhukov, B., Oertel, D. (2003). Fire radiative energy for quantitative study of biomass burning: Derivation from the bird experimental satellite and comparison to MODIS fire products. Remote Sens. Environ. 86, 83-107. https://doi.org/10.1016/S0034-4257(03)00070-1

Wooster, M.J., Xu, W., Nightingale, T. (2012). Sentinel-3 SLSTR active fire detection and FRP product: Pre-launch algorithm development and performance evaluation using MODIS and ASTER datasets. Remote Sens. Environ. 120, 236-254. https://doi.org/10.1016/j.rse.2011.09.033

World Health Organization (WHO) (2020). WHO urges caution as countries in Africa ease lockdowns. https://www.afro.who.int/news/who-urges-caution-countries-africa-ease-lockdowns (accessed 26 July 2020).

Zielinski, T., Petelski, T., Strzalkowska, A., Pakszys, P., Makuch, P. (2016). Impact of wild forest fires in eastern Europe on aerosol composition and particle optical properties. Oceanologia 58, 13-24. https://doi.org/10.1016/j.oceano.2015.07.005

Zubkova, M., Boschetti, L., Abatzoglou, J.T., Giglio, L. (2019). Changes in fire activity in Africa from 2002 to 2016 and their potential drivers. Geophys. Res. Lett. 46, 7643-7653. https://doi.org/1 $0.1029 / 2019$ GLO83469 